\title{
Migrants Crisis in the Southeast Europe
}

\author{
Mustafa Selçuk ${ }^{*}$ \\ mustafa.selcuk21@gmail.com
}

\begin{abstract}
The movement of more than a million immigrants to Europe has challenged European policies on the issue and shacked the very foundations of the European Union. Immigrants are not a new phenomenon in Europe especially in the Balkans (South East Europe) examined. The immigrant crisis that erupted in 2015 and 2016 was unique in terms of the number of people, the conditions and the emergencies created. Increased terrorism in Europe and huge number of immigrant arrived Europe via South East Europe, and initiation of immigrant campaigns in Europe on social media helping to immigrants for arrive to central Europe the same time states actor responses towards immigrants crisis. The purpose of this research figure out responses states actors in South East Europe towards immigrant crisis and European Union deal with Turkey. The concept of the research is understanding impact of immigrant crisis between 2015-2016 years, when one of huge number of immigrants arrived Europe and responses states actors South East Europe. The research technique mainly relies on sources such as journal articles, newspaper articles, on-line sources, and research center reports which are related with the immigrant crisis in South East Europe (Balkans) and Turkey. EU and Turkey deal jammed up because of political issues between EU and South East European countries overburdened towards immigrant crisis. While increased immigrant deaths in Aegean Sea positive view regarding to immigrants, even though increased terrorist incidents in Europe started negative view to immigrants.
\end{abstract}

Keywords: Greece, Immigrant Crisis, Refugee, Southeast Europe, Turkey

\begin{abstract}
Abstrak
Pergerakan lebih dari satu juta imigran ke Eropa telah menantang kebijakan Eropa mengenai isu imigran dan menggoyahkan landasan Uni Eropa yang telah mapan selama ini. Imigran bukan fenomena baru di Eropa terutama di Balkan (South East Europe). Krisis imigran yang meletus pada tahun 2015 dan 2016 sangat menarik pada aspek jumlah orang, kondisi dan keadaan darurat yang diciptakan. Meningkatnya terorisme di Eropa dan sejumlah besar imigran tiba di Eropa melalui Eropa Tenggara. Inisiasi kampanye imigran di Eropa melalui media sosial, membantu imigran untuk sampai ke Eropa Tengah pada saat yang sama menimbulkan krisis pada negara. Tujuan penelitian ini adalah untuk mengetahui tanggapan para aktor di Eropa Tenggara terhadap krisis imigran dan kesepakatan Uni Eropa dengan Turki. Konsep penelitian ini adalah pemahaman dampak krisis imigran antara tahun 2015-2016, ketika salah satu dari sejumlah besar imigran Eropa tiba, dan tanggapan negara aktor Eropa Tenggara. Teknik penelitian ini terutama mengandalkan sumber seperti artikel jurnal, artikel surat kabar, sumber daring, dan laporan pusat penelitian yang terkait dengan krisis imigran di Eropa Tenggara (Balkan) dan Turki. Kesepakatan Uni Eropa dan Turki macet karena adanya isu politik antara negara-negara Uni Eropa dan Eropa Tenggara yang terbebani krisis imigran. Sementara, insiden kematian imigran di Laut Aegea meningkatkan pandangan positif mengenai
\end{abstract}

*School of Journalism and Mass Media Communication, Faculty of Economic and Political Sciences Aristotle University Thessaloniki, Greece. mustafa.selcuk21@gmail.com 
masalah imigran, meskipun meningkatnya insiden teroris di Eropa mulai menunjukkan pandangan negatif kepada masalah imigran.

Kata kunci: Eropa Tenggara, Krisis Imigran, Pengungsi, Turki, Yunani

\section{Introduction}

Immigrants issue is not a new phenomenon in Europe especially in the Balkans (South East-Europe) examined. The migration crisis erupted in 2015 and 2016 was unique in terms of the number of people, the conditions and the emergencies created. According to the United Nations High Commissioner for Refugees (UNHCR, 2015), more than one million refugees and migrants arrived in Europe from the Middle East and North Africa during 2015. Of these, some 850,000 landed on the Greek islands. On 2106 387,739 arrived in Europe with the majority entering the EU via Greece (IOM report 2016). Many on board dangerously inadequate vessels run by people smugglers, according to figures just released by the UN Refugee Agency. Many immigrants dead in Aegean sea between 2015-2016 while they were trying to cross from Turkey to Greek islands also some of them dead cold weather condition or lack of basic humanitarian needs in Balkan route.

In additionally increase of uncontrolled transitions from borders, meanwhile an increase terrorist incidents in Europe revealed the importance of the crisis. European leaders arranged meeting for disscuss case of immigrants crisis. These developments affected a lot of public debate and dominated not only the national but the European public sphere as can be witnessed from the massive increase in discourse on immigrants in news articles, reporting's that were shared and debated on the social media as well. Huge number of migrants came to Europe via Turkey, therefore European leaders decided to deal with Turkey in order to prevent uncontrolled immigrants crossing borders. Political disagreement and increase tension between Europe and Turkey, European leaders started discussion plan B for migration crisis. The concept of the research is the understand to immigrant crisis in 2015-2016 when immigrants crisis erupted. How Southeast European countries and Turkey struggle toward migration crisis. Also how immigrant crisis effected Europe, responses state actors. The research technique of this paper mainly relies on sources such as journal articles, newspaper articles, on-line sources, books and research center reports which 
are related with the immigration crisis especially years of 2015-2016. Also official documents and official web-sites were prefered as sources.

\section{Migrant Route from Turkey to Western Balkans}

One of the route for Immigrants access to Europe is via Turkey to reach Greek islands, especially some of Greek islands are close to Turkey, which is easy for immigrants to reach Greece. In 2015 huge number of immigrants entered to Europe mostly from Syria and middle-east countries. According to the United Nations High Commissioner for Refugees (UNHCR), 1,000,573 refugees and migrants arrived in Europe from the Middle East and North Africa during 2015. Of these, 49 per cent were Syrian, 21 per cent Afghan and eight per cent Iraqi (leadbeater, 2016). Most of immigrants are Syrian who flee their country because of War in Syria. According to United Nation Refugee Agency UNHCR's latest figures show that increased of tragic migrant deaths in the Aegean Sea and 3,735 immigrants were missing, believed drowned in 2015 (UNHCR, 2015). With increasing immigrant deaths many people around world have been launched campaign for helping to immigrants. Social media played an active role in the execution of the campaigns.

\section{Table 1: The United Nation Refugee}

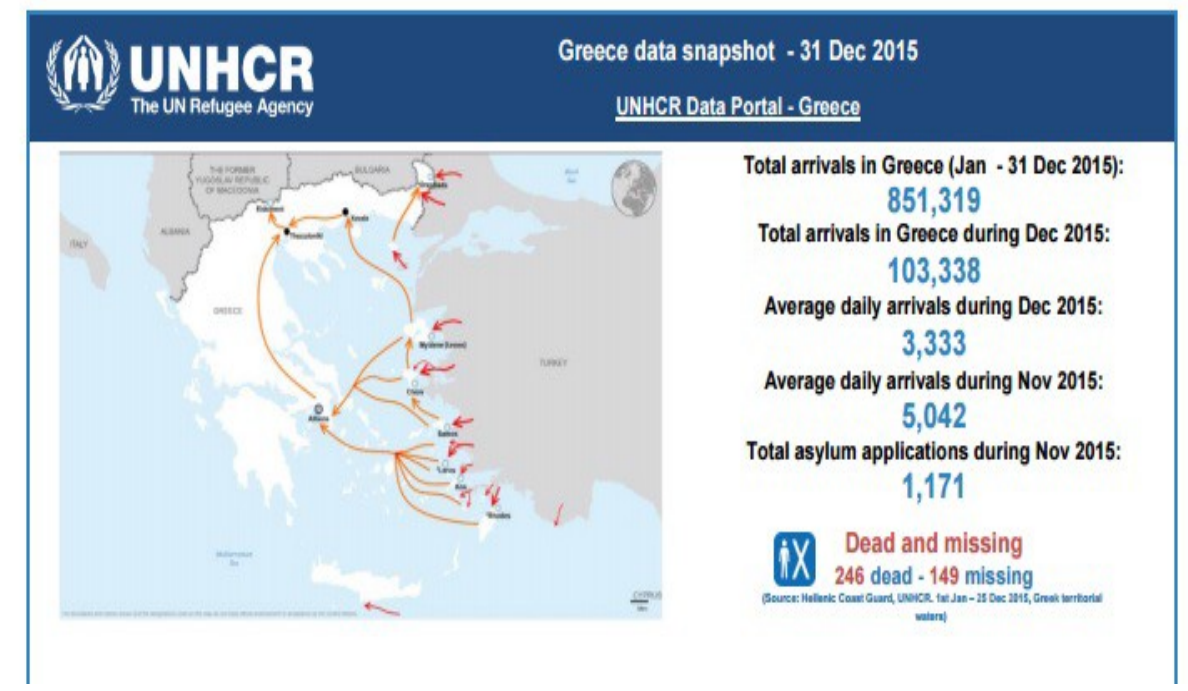

Source: The United Nation Refugee Agency, 31 December, 2015. Accessed in June 2017. 
Due to Turkey has one of the long boundary line with Syria, its easy way for immigrants access to Turkey. More than two milion Syrian they fled to Turkey since civil war started in Syria. Syrians are classified as temporary guests of the government in Turkey. Temporary protection proceedings that might provided to foreigners, who were forced to leave their countries and are unable to return to the countries they left and crossed borders in masses to seek urgent and temporary protection and whose international protection requests can not be taken under individual assessment (2014, Geçici Koruma Yönetmeliği Temporary Protection Regulation). Turkey authorities are not consider Syrians as permanently, which means its a transition country.

Ahmet Davutoğlu, when he was prime minister of Turkey, he said that, "We are ready to send to countries which open their doors to Syrians. But, unfortunately there is no offer from any states. I will write letters to world leaders to be the voice of Syrians for whom the international community has remained silent," He published on his Twitter account on 19 September 2015 (Haines, 2015).

The Greek islands close to Turkey, especially Chios, Kos, Lesbos, Leros are main route access to Europe for immigrants. Since 2009 Greece had has financial crisis thus central government focus on financial crisis and belt-tightening policy. The central government had no plan for handling the migrants surge at least not one they shared with the affected cities' mayors. Actually immigrants trying to go to central Europe, not staying in the South Eastern Europe, because central European countries are more developed and they have much more resources than South Eastern European countries. Nikos Kotzias, Greek foreign minister and member of the right-wing Independent Greeks party, first suggested a link between Greek immigration policy and negotiations with the European Union on the sidelines of an informal EU meeting in Riga last March. According to a Greek TV station, Kotzias said that "There will be millions of immigrants and thousands of jihadists who will come to Europe" if no deal is reached (Gaeten, 2015). In recent years the increased terrorist incidents in Europe, securitization.

Greece-Macedonia (FYROM) border is first border after immigrants entered Greece. They are trying to go to Idomeni village which is near border of Macedonia (FYROM) crossing border in order to arrive to central Europe. 
Macedonian authorities were repressive measures towards migrant crisis. Hundreds of refugees caught by the border police were forcibly pushed back over the border to Greece a clear violation of the Geneva refugee convention and the European Convention on Human Rights (Weber, 2016:6). Civil society organizations and many people have gone to Idomeni for humanitarian aid to immigrants. Social media was effective for implementation of aid campaign, especially many groups and pages opened on Facebook, for access to who willing to help to migrants. In additionally some hashtags was created by immigrant supporters (\#refugeeswelcome \#immigrants \#asylum) in order to spreading information regarding to case of immigrants. Many international news agencies punlished case of immigrants. New media influence on the foreign and domestic policy. Media has had two-headed role during migration crisis. While terrorist attack to Europe news coverage negative on migrants even though with increasing migrants deaths, media coverage turns positive image on migrants issue. The same echo occured in social media.

Figure 1: The Refugee in Greece

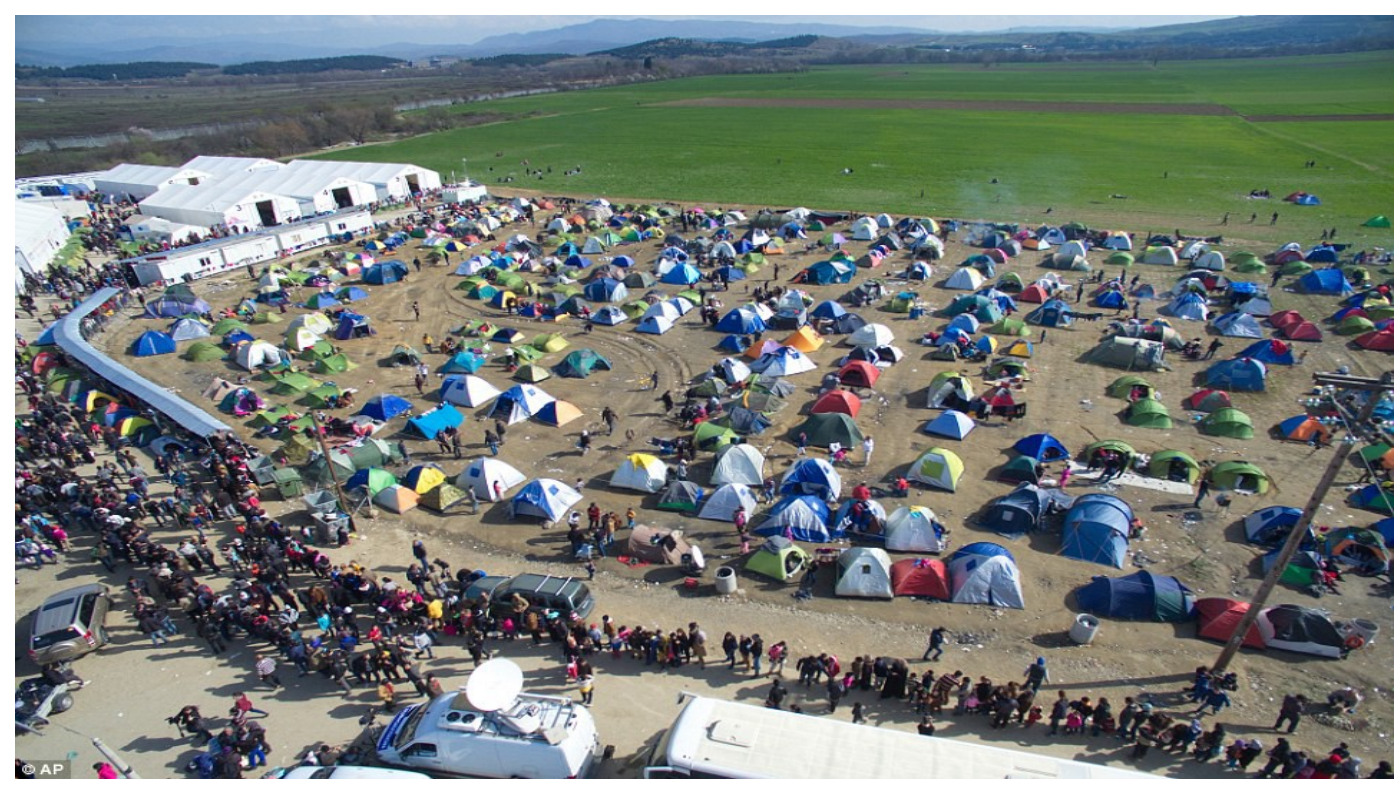

Source: The Associated Press, Idomeni, Greece Friday, 4 March 2016, accessed in June 2017.

With the increase of reactions, police violence tapered off, yet judging by available sources no investigations were ever undertaken. Alone sanctions imposed on police and border police officers because of in humane treatment of refugees and 
migrants faced with the exploding number of refugees and migrants, Macedonia declared a state of emergency on 20 August and closed the border to Greece (Weber, 2016:7). But after couple of days authorities give up, in Gevgelija which is closer to border of Greece opened migration reception center in order to manage the immigrants transit to Serbia. After exiting Macedonia, the refugees entered the last country on the Balkan route, Serbia.

Regarding to Serbia, since the beginning of 2015 more than 500.000 people have entered Serbia from the Former Yugoslav Republic of Macedonia, the flow of new refugees is estimated between 4.000 - 5.000 people per day on this route. Many of them are women and children (NATO, 2015). Since Yugoslavia collapsed there were no stable relation between Balkan countries, migrant crisis has intensified relations in the region. Tensions between Serbia and Croatia have escalated as the Balkan states struggle to come up with a way to deal with tens of thousands of refugees streaming through the two countries to seek sanctuary in other parts of Europe (Aljazeera, 2015).

Croatia was angry that Serbia is busing migrants to its border, rather than sending them north to Hungary. Croatian Prime Minister Zoran Milanovic on Thursday accused Serbia and Hungary of colluding (Aljazeera, 2015). Another hot spot is Hungarian border, several hundred immigrants camped between Hungary and Serbia border. Most of them Syrian who escaped from ISIS (Daesh) but their conditions is not that much well than Syria, because of cold weather conditions, sometimes exposure tear gas and basic humanitarian needs absence therefore some migrants dead on the Balkan route. Human Rights Watch said migrants were being kept in "abysmal" conditions at two detention centres in Roszke, lacking food and medical care.

In additionally, authorities give up strict control in borders they decided to accept Syrian immigrant in a controlled way, immigrants were evacuated from Greek border (Idomeni) to camps mainly in Thessaloniki and Kilkis. Above table indicates that Syrian migrants erupted in 2015. The European Union provides to Greece and also another member states with financial resources to support efforts in the areas of legal and irregular migration, return, asylum, border management and integration. During the 2014-20 period, the principal EU financial instruments supporting these areas are the Asylum, Migration and Integration Fund and the Internal Security Fund 
- Borders and Visa, under which $€ 3.6$ billion are allocated directly to Member States (European Commission). All those case resulted disscussion on migrant issue, some of media agencies published that why migrant coming Europe in steand of Arab or muslim countries while there are many contries around Syria and also this expression took place some of hashtags which is created by against migrants. First life expectance is high and second human rights and democracy then why migrants not staying in Turkey which is moderate country better than Arabic countries, actually Tukey already has more than two milion migrants, one of biggest number of migrants staying in Turkey (See Table 2).

Table 2. The Asylum in EU

\section{Top 10 origins of people applying for asylum in the EU}

First-time applications in 2015, in thousands

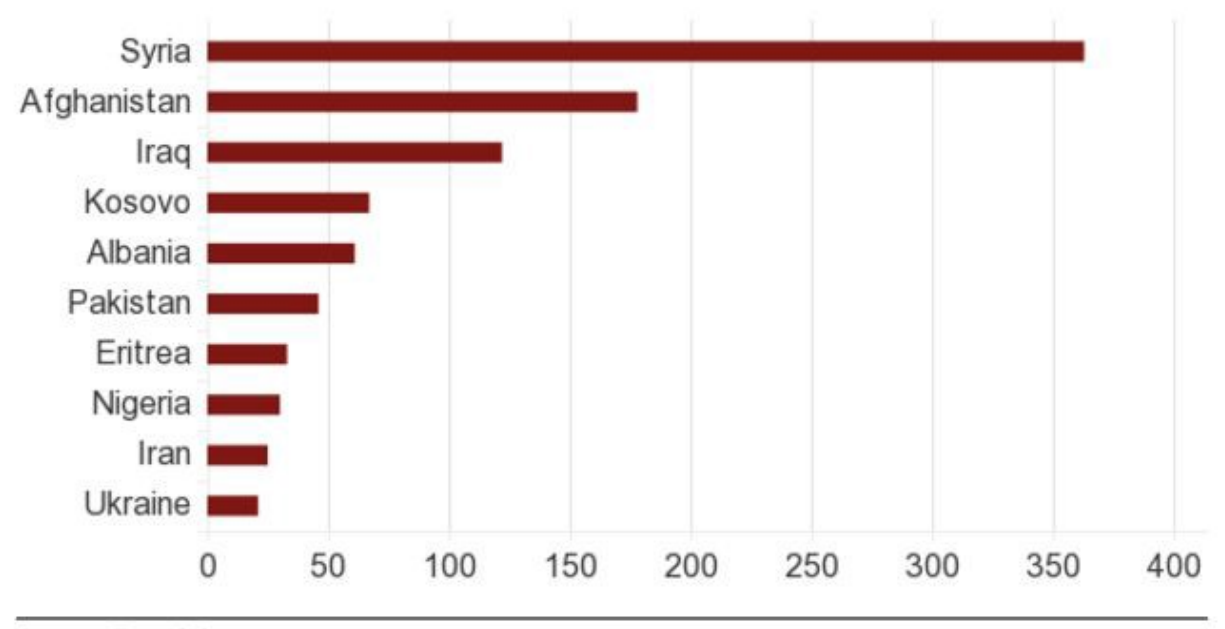

Source: Eurostat

\section{EU-Deal with Turkey}

In Europe, when immigrants entering a European country, they have to stay first entering country, they are not allowed to access to another European countries until their status changed. Turkey is not inside European Union therefore this regulation is not valid for Turkey. An unprecedented number of migrants especially from Syria, have sought to migrate via Turkish territory toward a better life in central Europe, this status opened theme in European parliement for deal between 
Europe and Turkey. This Action Plan reflects the understanding between the European Union and the Republic of Turkey to step up their cooperation on support of Syrians under temporary protection and migration management in a coordinated effort to address the crisis created by the situation in Syria (European CommissionFact sheet, 2015). It follows from the EU-Turkey working dinner on 17 May and the informal meeting of the EU Heads of State or Government on 23 September 2015 where EU leaders called for a reinforced dialogue with Turkey at all levels (European Commission-Fact sheet, 2015). Basically this action plan for Europe prevent irregular migration flows to the Europe. While European citizens can go to Turkey without a visa, even though Turkish citizens cannot enter Europe without visa. Intent of Turkey in this context is visa liberation for Turkish citizens to enter the Europe. In both sides define the actions that are to be at the same time by Turkey and the EU.

In 2016 still huge number of migrants crossed aegean sea via Turkey. Many politicians in Europe believed, that the plan with Turkey would fail. Some of European politicians against this plan with Turkey, they believed that, provision of monetary funds and visa liberation for Turkish citizens are not appropriate solution. Actually huge number of Turkish lives in Europe since Europe accepted economic worker from Turkey between 1964 -1970 years many Turkish migrated to Europe for work and they stayed in Europe. Some of European politician believed that, with the removal of the visas, the charm of Europe, possibility of Turkish immigrants coming to Europe. They argued for a viable and sustainable solution that did not rely on cooperation with Ankara (Dudden, 2019). European Union leaders pondering the migration crisis in Brussels on february 2016. They were discussed whether Turkey to curb the flow was enough or a "Plan B" to close Balkan borders is needed. The "Plan B" suggested by Poland, Hungary, Slovakia and the Czech Republic did not go down well in Brussels and Berlin. For one thing, closing borders would bottle up migrants in Greece, likely leading to major humanitarian problems in a country already struggling with its own deep economic crisis (Baczynska, 2016).

After the coup attempt in Turkey in 15 July 2016 resulting political tension between Brussel and Ankara. Erdoğan President of Turkey said that, If our want to citizen wants to death penalty we might implement for the soldiers who did coup attempt. European leaders expressed frustration with Turkey's domestic security and 
when President Erdoğan mentioned about death penalty. European parliament were requested Seventy-two criteria from Turkey for visa liberation but In five of these criteria dispute has arisen. In May 2016, the process came to a lock-in point before coup attempt thus July 15 coup attempt is not substantially affected EU and Turkey migrant deal.

\section{Conclusion}

European leaders returned from their summer break, they come across a new emergency the immgrant crisis. Increase of uncontrolled immigrant entering and unpresedented wave of immigrant entered Europe without integration and the other hand recent years increasing terrorist incidents in Europe as a result increased antiimmigrant perception in Europe. In initial days when huge number of migrant came to Europe there was strict border control. Increased migrant deads in Aegean Sea and police were beaten and unsig tear gas in the borders, and Hungary's initial reaction is considered the most drastic. Many European started protest in order to open the borders to immigrants. Immigrant crisis has become unmanageable (Souteast European countries overburdened and lack of coordination between countries.

The transit countries Southeast European) divergent responses affected bilateral relations. In August 2015, Germany exempted Syrian citizens from the rules of the Dublin Regulation, but removed the exemption in November. It reinstated border controls on its border with Austria in September, after receiving hundreds of thousands of migrants in a few days (Lilyanova, 2016). Austria builded a fence on the border with Slovenia. The immigrant crisis also brought to the fore the realisation that the Europe cannot act alone. Many migrants arriving to Europe via Turkey thus in order to find solution of this crisis need to collaboration with another countries which is not included shengen such as Serbia, Montenegro, Macedonia (FYROM), Albania, Turkey.

\section{References}

\section{Website}


Aljazeera News, (2015). “Tensions between Croatia and Serbia rise over refugees”, 25 $\begin{array}{llll}\text { September, } & 2015 . & \text { Retrieved }\end{array}$ http://www.aljazeera.com/news/2015/09/tensions-croatia-serbia-riserefugees-150924193440477.html, June 21,2017.

BBC News, (2015). "Migrant crisis: People treated 'like animals' in Hungary camp" 11 September 2015. Retrieved from http://www.bbc.com/news/worldeurope-34216883, July 20, 2017.

Baczynska, G. (2016). "EU leaders to discuss Turkey, 'Plan B' at migration diner", 18 February, 2016. Retrieved from http://uk.reuters.com/article/uk-europemigrants-eu-idUKKCN0VR1RA, 25 June 2017.

Dudden, L. (2017). “EU-Turkey Refugee Agreement: Too Big to Fail”, 5 June 2017.

Retrieved from http://setadc.org/eu-turkey-refugee-agreement-too-bigto-fail/, 25 June 2017.

European Commission, (2015). "EU-Turkey joint action plan”, Fact Sheet. Brussels, 15 October 2015. Retrieved fromhttp://europa.eu/rapid/pressrelease_MEMO-15-5860_en.htm 8 July 2017.

European Commission, (2015). “ANNUAL REPORT 2015 ON ASYLUM AND MIGRATION PART 2"European Migration Network Retrieved from https://ec.europa.eu/home-affairs/sites/homeaffairs/files/what-wedo/policies/european-agenda-migration/backgroundinformation/docs/funding_country_sheet_el_en.pdf, June 12, 2017.

Gaetan, V. (2015). “An Aegean Alliance Greece, Turkey, and Migration Cooperation", 29 September 2015. Retrieved from https://www.foreignaffairs.com/articles/greece/2015-09-29/aegeanalliance,

Geçici Koruma Yönetmeliği, (2014). (Temporary Protection Regulation), English translation available at http://www.goc. gov.tr/files/files/temptemp.pdf, Retrieved from https://perma.cc/9V29-HQZ5, June, 22, 2017.

Hurriyet daily newspaper, (2015). "Turkish PM to send letters to world leaders on behalf of Syrian refugees"20 September 2015. Retrieved from http://www.hurriyetdailynews.com/turkish-pm-to-send-letters-to- 
world-leaders-on-behalf-of-

syrian $\% 20$ refugees.aspx?pageID $=238 \& n I D=88746 \&$ NewsCatID $=338$, July 10, 2017.

Learbeater, C. (2016). "Which Greek islands are affected by the refugee crisis?" 3 March 2016. Retrieved from http://www.telegraph.co.uk/travel/destinations/europe/greece/articles /greek-islands-affected-by-refugee-crisis/,July 10, 2017.

Lilyanova, V. (2016). “The Western Balkans Frontline of the migrant crisis, European Parliamentary Research Service”, EPRS, 2016 January. Retrieved from http://www.europarl.europa.eu/RegData/etudes/BRIE/2016/573949/ EPRS_BRI(2016)573949_EN.pdf, June 23, 2017.

Mermin, J. (2010). "Conflict in the sphere of consensus?: Critical reporting on the Panama invasion and the Gulf War" Political Communication, 10 May 2010. $\quad$ Retrieved from http://www.tandfonline.com/doi/abs/10.1080/10584609.1996.9963106 , July 10, 2017.

NATO News, (2015). "Influx of refugees in Serbia", 17 December, 2015. Retrieved from http://www.nato.int/cps/pl/natohq/news_126095.htm, July 10, 2017.

The United Nations Refugee Agency, (2015). “Over one million sea arrivals reach Europein 2015”, 30 December 2015. Retrieved from http://www.unhcr.org/afr/news/latest/2015/12/5683d0b56/millionsea-arrivals-reach-europe-2015.html, July 10, 2017.

Weber, Bodo. (2016). "Time for a Plan B: The European Refugee Crisis, the Balkan Route and the EU-Turkey Deal, A report from Democratization”, Policy Council page-6-7, September 2016. 